\title{
Бојан Манојмовић
}

Факултет спорта и физичког васпитања, Универзитет у БеограАу

УAK 613.84:612-055.2

\section{УТИЦАЈ ПУШЕЊА НА НИВО ФУНКЦИОНААНИХ СПОСОБНОСТИ КАРАИОВАСКУААРНОГ СИСТЕМА КОА ЖЕНА УЗРАСТА ОА 20 АО 29 ГОАИНА}

\section{Сажетак}

У овом раду спроведено је истраживање са цињем да се процени способност максималног утрошка кисеоника код жена узраста оА 20 до 29 година и утврде евентуалне разлике у нивоу те способности код пушача и непушача, као и Аа се утврди евентуална повезаност пушачког стажа и интензитета са релативним максималним утрошком кисеоника. Узорак је обухватио 65 особа женског пола узраста оА 20 Ао 29 година (33 пушача и 32 непушача), које у претходних неколико месеци нису упражњавале неки облик редовне аеробне активности. На овом узорку спроведен је индиректни тест за процену максималног утрошка кисеоника - УКК тест ходања на $2 \mathrm{~km}$. На основу резултата Т-теста утврђена је статистички значајна разлика $(\mathrm{t}=0.01)$, за ниво значајности $\mathrm{p}<0.05$, између вреАности релативне максимацне потрошње кисеоника жена пушача и непушача, у корист непушача. Статистички значајна размика $(\mathrm{t}=0.02)$, за ниво значајности $\mathrm{p}<0.05$, утврђена је и између вреАности релативног максималног утрошка кисеоника израженог у односу на немасну компоненту телесне масе код жена пушача и непушача, у корист непушача. Такође, применом Т-теста, утврђено је Аа не постоји значајна разлика основних антропометријских показатеља жена пушача и непушача. Применом Пирсоновог коефицијента корелације утврђено је да између дужине пушачког стажа и интензитета пушења и максималног утрошка кисеоника жена пушача постоји ниска негативна повезаност $(-0,49)$. Резултати овог истраживања су потврдили резултате досадашњих истраживања о значајности разАике између способности максималног утрошка кисеоника коА пушача и непушача. Међутим, за разлику оА Аосадашњих истраживања, није доказана повезаност између максималног утрошка кисеоника и Аужине пушачког стажа и интензитета пушења.

Кьучне речи: РЕКРЕАЦИЈА/ЦИГАРЕТЕ/ $\mathrm{VO}_{2} \max$ 


\title{
INFLUENCE OF SMOKING ON THE LEVEL OF FUNCTIONAL ABILITIES OF CARDIOVASCULAR SYSTEM IN WOMEN AGED FROM 20 TO 29 YEARS
}

\begin{abstract}
In this thesis the survey was conducted in order to evaluate the ability of maximal oxygen consumption among women aged 20 to 29 years and to identify possible differences in the level of this ability in smokers and non-smokers, as well as to determine the possible correlation between the smoking period and intensity and relative maximum oxygen consumption. The sample included 65 females aged 20 to 29 years (33 smokers and 32 non-smokers), which in recent months haven't practiced some form of regular aerobic activity. This sample was taken in an indirect test for the assessment of maximal oxygen consumption - UKK $2 \mathrm{~km}$ walking test. Based on the results of T-test statistically significant difference $(t=0.01)$, for the level of significance $p<0.05$, was shown between the relative values of maximal oxygen uptake women smokers and non-smokers, in favor of non-smokers . A statistically significant difference $(t=0.02)$, for the level of significance of $p<0.05$, was found between the relative values of maximal oxygen consumption expressed in relation to lean body mass component in women smokers and non-smokers, in favor of non-smokers. Also, using the T -test, it was found that there was no significant difference in basic anthropometric indicators of women smokers and nonsmokers. By using Pearson's correlation coefficient it was found that between smoking duration and intensity of smoking and maximal oxygen consumption of women smokers exists a low negative correlation (-0.49). Results of this study confirmed the results of previous researches on the significance of the difference between the ability of maximal oxygen consumption among smokers and non-smokers. However, unlike previous studies , correlation between maximal oxygen consumption and smoking duration and intensity of smoking has not been proven.
\end{abstract}

Key words: RECREATION/CIGARETTES/ $\mathrm{VO}_{2} \max$ 


\section{УВОА}

Пушење цигарета је фактор ризика за око 30 болести са високом стопом обољевања и смртности (Чоп-Блажић и Заворео, 2009). Истовремено пушење цигарета је водећи узрочник болести и смртности у свету који се може спречити. Међутим, с обзиром да продаја цигарета доноси огроман новац, дуванска индустрија за сада успешно одолева бројним иницијативама за забрану пушења. Оно што је специфично у овом случају је и то што се ни пушачи не оАричу мако цигарета. ГАавни узрок томе је никотин, супстанца која проузрокује како психичку, тако и физичку зависност оА пушења. На тај начин цигарете у животу пушача заузимају високо место на мисти приоритета. Снажни симптоми које изазива апстиненција оА цигарета, чине их неопходним за нормахно функционисање психе пушача. Често пушење цигарета постаје и ритуац, па извесне животне ситуације пушач не може ни замислити без цигарете. У задовољавању своје потребе, пушачи су врло често безобзирни и егоистични, па су, у много ситуација, и непушачи у њиховој околини принуђени да пасивно удишу Аувански дим, што се такође показало као веома штетно по зАравље. Аувански Аим свој штетни утицај испољава пре свега на респираторни систем, али су штетном утицају непосреАно или посреАно изможени и остали органски системи.

Сврха овог мастер рада је да се установи да ми постоји и каква је природа утицаја пушења цигарета на ниво функционалних способности кардиоваскуларног система коА женске попукације узраста оА 20 Ао 29 година.

Циь истраживања је био Аа се процени способност максималног утрошка кисеоника код жена узраста оА 20 Ао 29 година и утврде евентуанне разлике у нивоу те способности коА пушача и непушача, као и Аа се утврди евентуанна повезаност пушачког стажа и интензитета са релативним максималним утрошком кисеоника.

На основу теоријских сазнања и резултата досадашњих истраживања поставьене су следеће хипотезе:

Х1 - Постоји значајна разлика између процењеног релативног максимацног утрошка кисеоника коА жена пушача и непушача узраста оА 20 Ао 29 година, у корист непушача.

Х2 - Постоји значајна разлика између процењеног релативног максималног утрошка кисеоника израженог у односу на немасну компоненту телесне масе коА жена пушача и непушача узраста оА 20 Ао 29 година, у корист непушача.

Х3 - Постоји висока негативна повезаност Аужине пушачког стажа и интензитета пушења са процењеним релативним максималним утрошком кисеоника коА жена пушача узраста оА 20 Ао 29 година.

$\mathrm{X} 4$ - Не постоји значајна разлика у основним антропометријским показатељима између жена пушача и непушача узраста од 20 Ао 29 година. 


\section{МЕТОА ИСТРАЖИВАҢА}

У овом раАу је извршено екс-пост-факто истраживање у коме је примењен аналитички метод и то Аескриптивни (основни показатељи антропометријских карактеристика и мерених способности испитаника) и компаративни (откривање разлика и повезаности унутар преАмета истраживања применом т-теста и Пирсоновог коефицијента корекације).

Методологија истраживања је обухватила ток и поступке истраживања, узорак испитаника, узорак варијабли, мерне инструменте и статистичку обраду података.

\section{Ток и поступци истраживања}

Истраживање је реализовано кроз три фазе. То су:

1. Анкета

2. Антропометрија испитаника

3. Тест за процену нивоа максималног утрошка кисеоника - УКК тест ходања на $2 \mathrm{~km}$.

\section{Узорак испитаника}

Узорак испитаника је изведен из попукације женског пола узраста оА 20 Ао 29 година са боравком на територији граАа Београда.

Узорак је сачињавало 65 особа женског пола које су испуњавале задати узрасни услов као и услов Аонекме сеАентарног начина живота (Аа се у протеклих неколико месеци нису редовно (3 и више пута недењно) бавиле неким обликом систематског аеробног вежбања). Узорак је потом подењен у Ава субузорка у оАносу на критеријум Аа $\Lambda$ упражњавају пушење цигарета или не. На тај начин се изАвојио субузорак оА 33 пушача и 32 непушача.

\section{Узорак варијабми}

Статистичка анализа вршена је на основу следећих варијабли:

- Пушач (да ики не)

- NKTM (немасна компонента телесне масе)

- $\mathrm{VO}_{2} \max$ (релативни максимални утрошак кисеоника)

- $\mathrm{VO}_{2} \mathrm{max} / \mathrm{kg} \mathrm{NKTM}$ (релативни максимални утрошак кисеоника изражен по килограму немасне компоненте телесне масе)

- UBPC (укупан број попушених цигарета, изражен као производ Аужине пушачког стажа и интензитета пушења) 


\section{Мерни инструменти}

Мерни инструменти коришћени за потребе овог истраживања су били анкета, антропометрија и УКК тест ходања на $2 \mathrm{~km}$.

Анкета је садржала следећа питања:

1. Име и презиме:

2. Аатум рођења:

3. Пушач: АА ими НЕ

4. Аа $и$ је у послеАњих неколико месеци упражњавана редовна (3 или више пута недељно) аеробна активност (брзо ходање, трчање, пливање, аеробик...)?

5. Пушачки стаж (на нивоу месеца):

6. Интензитет пушења (колико цигарета Аневно):

Антропометрија испитаника саАржала је Ава задатка:

1. Мерење висине тела испитаника (конгитудинална мера)

2. Мерење телесне масе и телесне композиције испитаника (циркукарна мера)

На основу количника телесне масе $(\mathrm{kg})$ и квадрата телесне висине $\left(\mathrm{m}^{2}\right)$ израчунат је индекс телесне масе (BMI).

Телесна висина мерена је антропометром по Мартину, а телесна маса и композиција мерене су вагом са биоимпеАанцом TANITA BC-601.

За процену нивоа максималног утрошка кисеоника одабран је УКК тест ходања на $2 \mathrm{~km}$. Овај тест за индиректну процену максималног утрошка кисеоника одабран је због своје безбедности, поузданости и једноставности. ВалиАност и поузданост овог теста потврђена је и одређеним истраживањима (Rance et al. 2005; Zakarias et al. 2003; Laukkanen et al. 1992). Протокоц теста захтева поштовање температуре ваздуха у распону оА $5-25{ }^{\circ} \mathrm{C}$, умерену влажност, комотну одећу или тренерку и оАговарајућу обућу или патике, загревање оА 5 до 10 минута: истезање мишића кичменог стуба и ногу и брзо ходање око $200 \mathrm{~m}$. Пулс се мери тако што испитаник стави Алан Аесне руке на груди у висини врха срца и броји пулс у трајању од 20 секунди, одмах по завршетку теста ходања, и добијену вредност помножи са 3 и то се уноси у формуку (Митић, 2001). Тест се може изводити на треАмилу или у теренским условима (атлетска стаза и Ар.). У овом случају тест је спроведен на треАмилу, а пулс је мерен помоћу пулсметра SIGMA Onyx easy. Просторија у којој је био извођен тест је била кмиматизована што је омогућияо испуњење услова за температуру ваздуха. На основу добијених података, коришћењем следеће формуле (за особе женског пола) добија се вредност релативног максималног утрошка кисеоника (Митић, 2001):

116.2-2.98 х време-0.11 х пулс-0,14 х године- 0.39 х ВMI $=\mathrm{VO}_{2} \max (\mathrm{ml} / \mathrm{kg} / \mathrm{min})$ Време се обрачунава на следећи начин: 15 мин и 30 сек $=15.50$ мин 


\section{Обрада података}

Статистичка обрада података извршена је у програму Microsoft Office Excel 2007.

За израчунавање основних показатеља антропометријских карактеристика и мерене способности испитаника коришћена је дескриптивна статистика: аритметичка средина (MEAN), стандардна девијација (SD), минимална вреАност (MIN), максимална вредност (MAX), опсег (RANGE) и коефицијент варијације (V\%).

За израчунавање значајности разцике процењеног релативног максималног утрошка кисеоника групе пушача и непушача и значајности разАике процењеног релативног максималног утрошка кисеоника израженог у односу на немасну компоненту телесне масе пушача и непушача коришћен је Авосмерни Т-тест за независне узорке. Иста статистичка процедура коришћена је и за израчунавање значајности разлике аритметичких средина основних антропометријских показатеьа жена пушача и непушача.

За израчунавање повезаности дужине пушачког стажа и интензитета пушења са процењеним релативним максималним утрошком кисеоника коА пушача коришћен је Пирсонов коефицијент корекације.

\section{РЕЗУАТАТИ ИСТРАЖИВАЬА}

Резултати истраживања ће због боље прегледности бити истакнути табеларно.

Табела 1. Аескриптивни параметри основних показатеља антропометријских карактеристика и измерених способности жена пушача узраста оА 20 Ао 29 година.

\begin{tabular}{lrrrrrr}
\hline Параметри & MEAN & SD & MIN & MAX & RANGE & V\% \\
\hline Године старости & 24.5 & 2.7 & 20 & 29 & 9 & 11 \\
Пушачки стаж & 67.5 & 37.0 & 18 & 156 & 138 & 55 \\
Интензитет пушења & 17.0 & 6.8 & 5 & 30 & 25 & 40 \\
UВРC & 34936.4 & 24081.8 & 3600 & 93600 & 90000 & 69 \\
TV (cm) & 169.7 & 5.6 & 160 & 186 & 26 & 3 \\
TM (kg) & 64.7 & 11.0 & 53.7 & 90.1 & 36.4 & 17 \\
ВМI (kg/m2) & 22.4 & 3.3 & 18.8 & 29.8 & 11.0 & 15 \\
NКTM (kg) & 44.4 & 5.5 & 38.1 & 58.7 & 20.6 & 12 \\
VO2max (ml/kg/min) & 34.4 & 3.0 & 30.6 & 43.6 & 13.0 & 9 \\
VO2max/NKTM (ml/kg NKTM/min) & 49.9 & 4.4 & 42.6 & 61.6 & 18.9 & 9 \\
УКK Време (s) & 1035.9 & 51.9 & 857.0 & 1131.0 & 274.0 & 5 \\
\hline
\end{tabular}


Табела 2. Аескриптивни параметри основних показатеља антропометријских карактеристика и измерених способности жена непушача узраста оА 20 Ао 29 година.

\begin{tabular}{lrrrrrr}
\hline Параметри & MEAN & SD & MIN & MAX & RANGE & V\% \\
\hline Године старости & 24.5 & 2.7 & 20 & 29 & 9 & 11 \\
TV (cm) & 167.6 & 4.4 & 161 & 180 & 19 & 3 \\
TM (kg) & 61.8 & 12.1 & 48.4 & 95.2 & 46.8 & 20 \\
BMI (kg/m2) & 22.0 & 4.3 & 17.3 & 34.5 & 17.3 & 19 \\
NKTM (kg) & 42.2 & 3.6 & 36.0 & 50.1 & 14.1 & 8 \\
VO2max (ml/kg/min) & 36.5 & 2.9 & 29.1 & 41.9 & 12.8 & 8 \\
VO2max/NKTM (ml/kg NKTM/min) & 53.0 & 6.2 & 39.1 & 69.1 & 30.0 & 12 \\
УКК Време (s) & 991.4 & 56.9 & 868.0 & 1179.0 & 311.0 & 6 \\
\hline
\end{tabular}

Табела 3. Значајност разлика (Т-тест) аритметичких средина релативног максималног утрошка кисеоника и релативног максималног утрошка кисеоника израженог у односу на немасну компоненту телесне масе код жена пушача и непушача узраста оА 20 Ао 29 година.

\begin{tabular}{|c|c|c|c|c|}
\hline Параметри & Пушачи (просек) & $\begin{array}{r}\text { Непушачи } \\
\text { (просек) } \\
\end{array}$ & Т-тест & $\begin{array}{r}\text { T-тест ниво } \\
\text { значајности } \\
\end{array}$ \\
\hline VO2max (ml/kg/min) & 34.4 & 36.5 & 0.01 & 0.05 \\
\hline VO2max/NKTM (ml/kg NKTM/min) & 49.9 & 53.0 & 0.02 & 0.05 \\
\hline
\end{tabular}

Табема 4. Повезаност укупног броја попушених цигарета (као производ Аужине пушачког стажа и интензитета пушења) са релативним максималним утрошком кисеоника коА жена пушача узраста оА 20 Ао 29 година.

\begin{tabular}{ccrrrrrrr}
\hline $\begin{array}{c}\text { Испи- } \\
\text { таник }\end{array}$ & UBPC & $\begin{array}{r}\text { VO2max } \\
(\mathbf{m l} / \mathbf{k g} / \mathbf{m i n})\end{array}$ & $\begin{array}{c}\text { Испи- } \\
\text { таник }\end{array}$ & UBPC & $\begin{array}{r}\text { VO2max } \\
(\mathbf{m l} / \mathbf{k g} / \mathbf{m i n})\end{array}$ & $\begin{array}{c}\text { Испи- } \\
\text { таник }\end{array}$ & UBPC & $\begin{array}{r}\text { VO2max } \\
(\mathbf{m l} / \mathbf{k g} / \mathbf{m i n})\end{array}$ \\
\hline 1 & 32400 & 35.3 & 12 & 18000 & 33.0 & 23 & 28800 & 33.7 \\
2 & 21600 & 33.8 & 13 & 13500 & 38.5 & 24 & 43200 & 31.5 \\
3 & 57600 & 30.6 & 14 & 7200 & 37.0 & 25 & 54000 & 30.9 \\
4 & 93600 & 30.9 & 15 & 72000 & 30.8 & 26 & 27000 & 39.6 \\
5 & 14400 & 34.8 & 16 & 3600 & 38.7 & 27 & 39600 & 33.8 \\
6 & 7200 & 31.1 & 17 & 10800 & 33.1 & 28 & 79200 & 33.5 \\
7 & 72000 & 30.9 & 18 & 27000 & 38.5 & 29 & 21600 & 37.8 \\
8 & 54000 & 33.9 & 19 & 7200 & 32.4 & 30 & 21600 & 43.6 \\
9 & 72000 & 33.3 & 20 & 43200 & 32.1 & 31 & 36000 & 34.4 \\
10 & 10800 & 36.1 & 21 & 50400 & 35.1 & 32 & 10800 & 33.4 \\
11 & 16200 & 36.3 & 22 & 43200 & 34.7 & 33 & 43200 & 32.5 \\
\hline
\end{tabular}

Pirsonov koef.

Korelacije

$-0.49$ 
Табела 5. Значајност разлика (Т-тест) аритметичких средина основних антропометријских показатеља жена пушача и непушача узраста оА 20 Ао 29 година.

\begin{tabular}{lrrrr}
\hline Параметри & $\begin{array}{r}\text { Пушачи } \\
\text { (просек) }\end{array}$ & $\begin{array}{r}\text { Непушачи } \\
\text { (просек) }\end{array}$ & T-тест & T-test ниво знач. \\
\hline TV (cm) & 169.7 & 167.6 & 0.10 & 0.05 \\
TM (kg) & 64.7 & 61.8 & 0.32 & 0.05 \\
BMI (kg/m m $^{2}$ & 22.4 & 22.0 & 0.66 & 0.05 \\
NKTM (kg) & 44.4 & 42.2 & 0.06 & 0.05 \\
\hline
\end{tabular}

\section{АИСКУСИЈА}

У табели 1, приказани су дескриптивни параметри основних показатеља антропометријских карактеристика и измерених способности жена пушача узраста оА 20 Ао 29 година. Просечна вреАност узраста износи $24.5 \pm 2.7$ година, телесне висине $169.7 \pm 5.6 \mathrm{~cm}$, телесне масе $64.7 \pm 11 \mathrm{~kg}$, индекса телесне масе 22.4 $\pm 3.3 \mathrm{~kg} / \mathrm{m}^{2}$, немасне компоненте телесне масе $44.4 \pm 5.5 \mathrm{~kg}$, релативног максималног утрошка кисеоника $34.4 \pm 3 \mathrm{ml} / \mathrm{kg} / \mathrm{min}$, и релативног максималног утрошка кисеоника израженог у односу на немасну компоненту телесне масе $49,9 \pm 4.4 \mathrm{ml} /$ $\mathrm{kg} \mathrm{NKTM/min.}$

У табели 2, приказани су дескриптивни параметри основних показатеља антропометријских карактеристика и измерених способности жена непушача узраста оА 20 Ао 29 година. Просечна вредност узраста износи $24.5 \pm 2.7$ година, телесне висине $167.6 \pm 4.4 \mathrm{~cm}$, телесне масе $61.8 \pm 12.1 \mathrm{~kg}$, индекса телесне масе $22.0 \pm 4.3 \mathrm{~kg} / \mathrm{m}^{2}$, немасне компоненте телесне масе $42.2 \pm 3.6 \mathrm{~kg}$, релативног максималног утрошка кисеоника $36.5 \pm 2.9 \mathrm{ml} / \mathrm{kg} / \mathrm{min}$, и релативног максималног утрошка кисеоника израженог у односу на немасну компоненту телесне масе 53 $\pm 6.2 \mathrm{ml} / \mathrm{kg} \mathrm{NKTM} / \mathrm{min}$.

У табели 3, приказана је значајност разлика аритметичких средина релативног максималног утрошка кисеоника и релативног максималног утрошка кисеоника израженог у односу на немасну компоненту телесне масе код жена пушача и непушача узраста оА 20 Ао 29 година. Просечна вреАност релативног максимацног утрошка кисеоника коА жена пушача износи $34.4 \pm 3 \mathrm{ml} / \mathrm{kg} / \mathrm{min}$, а коА жена непушача износи $36.5 \pm 2.9 \mathrm{ml} / \mathrm{kg} / \mathrm{min}$. На основу резултата Т-теста може се констатовати да постоји статистички значајна разлика $(\mathrm{t}=0.01)$ за ниво статистичке значајности оА 0.05 . Тиме је прихваћена хипотеза X1 овог истраживања. Резултати овог истраживања потврдики су резултате неких претходних истраживања (Chatterjee and assoc., 1987; Bernaards and assoc., 2003; Suminski and assoc., 2009).

Из табеле 3, такође се види да просечна вредност максималног утрошка кисеоника израженог у односу на немасну компоненту телесне масе код жена пушача износи $49.9 \pm 4.4 \mathrm{ml} / \mathrm{kg} \mathrm{NKTM} / \mathrm{min}$, а коА жена непушача износи $53 \pm 6.2$ 
$\mathrm{ml} / \mathrm{kg}$ NKTM/min. На основу резултата Т-теста може се констатовати Аа постоји статистички значајна разАика $(\mathrm{t}=0.02)$ за ниво статистичке значајности оА 0.05 . Тиме је прихваћена хипотеза Х2 овог истраживања.

У табели 4, приказана је повезаност укупног броја попушених цигарета (као производ Аужине пушачког стажа и интензитета пушења) са релативним максималним утрошком кисеоника код жена пушача узраста оА 20 Ао 29 година. ВреАност Пирсоновог коефицијента корелације $(-0,49)$ показује ниску негативну повезаност између укупног броја попушених цигарета и релативног максималног утрошка кисеоника коА жена пушача. На основу ових резумтата одбацује се хипотеза Х3 овог истраживања. Иако је досадашњим истраживањима (Ingemann-Hansen and Halkjaer-Kristensen, 1977; Chatterjee and assoc., 1987) Aoказана негативна повезаност између укупног броја попушених цигарета и релативног максимацног утрошка кисеоника (ова истраживања су рађена на мушкој попукацији), у овом скучају та повезаност се показала као ниска. Разцог за овакву појаву могу бити фактори које тешко можемо ставити поА контролу, попут, на пример, мотивације за остварење што бољег резултата на тесту, времена оА последње попушене цигарете Ао почетка теста итА. Наравно, резултати овог истраживања морају се узети са извесном дозом резерве јер је узорак био релативно мали, па је самим тим и уопштавање на основни скуп могуће у много мањој мери.

У табели 5, приказана је значајност размика аритметичких средина основних антропометријских показатеља жена пушача и непушача узраста оА 20 Ао 29 година. Просечна вредност телесне висине коА жена пушача износи $169.7 \pm 5.6$ $\mathrm{cm}$, а код жена непушача износи $167.6 \pm 4.4 \mathrm{~cm}$. На основу резултата Т-теста може се констатовати да не постоји статистички значајна разАика $(\mathrm{t}=0.10)$ за ниво статистичке значајности оА 0.05 . Просечна вреАност телесне масе коА жена пушача износи $64.7 \pm 11 \mathrm{~kg}$, а код жена непушача $61.8 \pm 12.1 \mathrm{~kg}$. На основу резултата Т-теста може се констатовати Аа не постоји статистички значајна разАика $(\mathrm{t}=0.32)$ за ниво статистичке значајности оА 0.05 . Просечна вредност индекса телесне масе коА жена пушача износи $22.4 \pm 3.3 \mathrm{~kg} / \mathrm{m}^{2}$, а код жена непушача износи $22.0 \pm 4.3$ $\mathrm{kg} / \mathrm{m}^{2}$. На основу резултата Т-теста може се констатовати Аа не постоји статистички значајна разлика $(\mathrm{t}=0.66)$ за ниво статистичке значајности оА 0.05. Просечна вреАност немасне компоненте телесне масе коА жена пушача износи 44.4 $\pm 5.5 \mathrm{~kg}$, а код жена непушача $42.2 \pm 3.6 \mathrm{~kg}$. На основу резултата Т-теста може се констатовати Аа не постоји статистички значајна разАика $(\mathrm{t}=0.06)$ за ниво статистичке значајности оА 0.05 . На основу ових резултата прихвата се хипотеза X4 овог истраживања. C' обзиром Аа не постоји значајна размика међу антропометријским показатељима жена пушача и непушача, може се рећи да они нису у већој мери утицали на показану разлику у максималном утрошку кисеоника. 


\section{ЗАКЬУЧАК}

Аувански Аим свој штетни утицај испољава пре свега на респираторни систем, аци су штетном утицају непосреАно ими посреАно изцожени и остали органски системи. Пушење цигарета изазива ограничен проток ваздуха кроз респираторни систем, сужење Аисајних путева, Аеструкцију плућног ткива, губитак везе између алвеола и малих Аисајних путева, смањење еластичности плућног ткива, вазоконстрикцију крвних судова, повећање крвног притиска и повећање могућности за формирање тромба. Угьен-моноксид (CO) који се налази у Ауванском Аиму значајно смањује функционалност еритроцита односно умањује способност хемоглобина да веже кисеоник. На овај начин Аолази и до смањења максимацног утрошка кисеоника (мера максимацне аеробне моћи) појеАинца.

Истраживање је спроведено на узорку од 65 особа женског пола узраста оА 20 Ао 29 година, које у претходних неколико месеци нису упражњавале неки облик редовне аеробне активности. На узорку је примењен УКК тест ходања на $2 \mathrm{~km}$ Аа би се на индиректан начин проценима њихова способност максимацног утрошка кисеоника. Аобијени подаци обрађени су коришћењем аналитичког дескриптивног и компаративног (Т-тест, корекација) метода. На основу резултата Т-теста утврђена је статистички значајна размика $(\mathrm{t}=0.01)$, за ниво значајности $\mathrm{p}<0.05$, између вредности релативне максималне потрошње кисеоника жена пушача и непушача, у корист непушача, чиме је прихваћена хипотеза X1 овог истраживања. Статистички значајна размика $(\mathrm{t}=0.02)$, за ниво значајности $\mathrm{p}<0.05$, утврђена је и између вредности релативног максималног утрошка кисеоника израженог у односу на немасну компоненту телесне масе код жена пушача и непушача, у корист непушача, чиме је прихваћена хипотеза Х2 овог истраживања. Такође, применом Т-теста, утврђено је да не постоји значајна размика основних антропометријских показатеьа жена пушача и непушача, чиме је прихваћена хипотеза X4 овог истраживања. Применом Пирсоновог коефицијента коремације утврђено је да између дужине пушачког стажа и интензитета пушења и максималног утрошка кисеоника жена пушача постоји ниска негативна повезаност $(-0,49)$, чиме је одбачена хипотеза Х3 овог истраживања.

Резултати овог истраживања су потврдики резултате досаАашњих истраживања о значајности разлике између способности максимацног утрошка кисеоника код пушача и непушача. Тиме је свакако потврђено Аа постоји штетан утицај пушења на ниво функционацних способности карАиваскуларног система код жена пушача узраста од 20 Ао 29 година. Међутим, за разлику од Аосадашњих истраживања, није Аоказана повезаност између максимацног утрошка кисеоника и дужине пушачког стажа и интензитета пушења.

Аопринос овог истраживања је у томе што Ао сада није рађено много оваквих истраживања на женској попукацији, већ су испитаници углавном бими мушкарци. Међутим, с обзиром на релативно махи узорак, резултати овог истраживања се морају узети са извесном дозом резерве приликом уопштавања на основни скуп. У сваком случају, ово истраживање може послужити као подстицај свим заинтересованим истраживачима да потпуније истраже овај проблем. 


\section{МИТЕРАТУРА}

1. Bernaards, C., Twisk, J., Van Mechelen, W., Sbel, J.and Kemper, H. (2003): A longitudinal study on smoking in relationship to fitness and heart rate response. Medicine and Science in Sports and Exercise, 35(5), 793-800.

2. Zakarias, G., Petrekanits, M. and Laukkanen, R. (2003): Validity of a 2-km Walk Test in predicting the maximal oxygen uptake in moderately active Hungarian men. European Journal of Sport Science, 3(1), 1-8.

3. Ingemann-Hansen,T. and Halkjaer- Kristensen, J. (1977): Cigarette smoking and maximal oxygen consumption rate in humans. Scandinavian Journal of Clinical \& Laboratory Investigation, 37 (2), 143-148.

4. Laukkanen, R., Oja, P., Pasanen, M. and Vuori, I. (1992): Validity of a two kilometre walking test for estimating maximal aerobic power in overweight adults. International Journal of Obesity and Related Metabolic Disorders: Journal of the International Association for the Study of Obesity, 16 (4), 263-268.

5. Митић, А. (2001): Рекреација. Факултет спорта и физичког васпитања, БеограА.

6. Rance, M., Boussuge, P.-Y., Lazaar, N., Bedu, M., Van Praagh, E., Dabonneville, M. and Duché, P (2005): Validity of a VO2max Prediction Equation of the $2 \mathrm{~km}$ Walk Test in Female Seniors. International Journal of Sports Medicine, 26 (6), 453-456.

7. Suminski, RR., Wier, LT., Poston, W., Arenare, B., Randles, A. and Jackson AR. (2009): The effect of habitual smoking on measured and predicted VO2(max). Journal of Physical Activity \& Health, 6 (5), 667-673.

8. Chatterjee, S., Dey, SK. and Nag SK. (1987): Maximum oxygen uptake capacity of smokers of diferent age group. The Japanese Journal of Physiology, 37 (5), 837-850.

9. Чоп-Бцажић, Н. и Заворео, И. (2009): There is no healthy level of smoking. Acta Clinica Croatica, 21 (3), 371-376. 